\title{
Die wit kerk en swart nood: Is daar nog sout in die soutpot oor? Opmerkings oor die betrokkenheid van die wit kerk by die MIV/Vigs pandemie in Suid-Afrika ${ }^{1}$
}

\author{
L G Schoeman, P Verster (Universiteit van die Vrystaat) \\ en J J Kritzinger (Universiteit van Pretoria)
}

\section{ABSTRACT}

The white church and black needs: Is there still salt left in the salt cellar? Remarks on the involvement of the white church with the HIV/Aids pandemic in South Africa.

There are reasons why the churches in the white community of South Africa are not really concerned or involved in the HIV/Aids pandemic, which is primarily ravaging the Black community. This may, however, be regarded as the "shibolet" for the credibility of the church. The article emphasises the need for the (White) church to listen in three directions: to understand its own identity, to listen (again) to the will of the Lord, and to listen to the needs of the Black community (especially in terms of HIV/Aids). Then the church should become involved. This involvement must be above else in the local communities, in the practical ways, which are indicated, in the area of short-term help, but also empowerment and liberation.

\section{DIE NOOD IN DIE SWART GEMEENSKAP IN DIE NUWE SUID-AFRIKA IS VER VERWYDERD VAN DIE LEEFWÊRELD VAN DIE TRADISIONELE BLANKE KERK}

Teen alle euforiese verwagtinge in, is die swart gemeenskap in die nuwe Suid-Afrika nie veel beter daaraan toe nie. Ou en nuwe krisisse duik gereeld op. Ek wil in hierdie artikel my aandag bepaal by die MIV/Vigs pandemie. Sonder om bekende statistiek en beramings te herhaal, moet die saak op die tafel geplaas word met ' $n$ baie duidelike en voor die hand liggende tipering.

- Hoe armer gemeenskappe is, hoe 'n groter verwoesting saai hierdie pandemie. Voorkomende aksie en lewensverlengende behandeling word bemoeilik deur armoede.

- Veral die seksueel aktiewe jeug (en die sagte teikens: vroue) word die hardste getref deur hierdie pandemie.

- Persentasiegewys word die swart gemeenskap tans swaarder getref as die ander gemeenskappe in SA.

$1 \quad$ Gebaseer op die navorsing vir die DTh verhandeling ingedien aan die Universiteit van die Vrystaat. Die promotors was proff P Verster (UV) en J J Kritzinger (UP). 
Hierteenoor is die wit kerke (en by name die NG Kerk) meer verteenwoordigend van die huidige middelklas, meer bejaarde, wit gemeenskap. Die kerkleierskap is oorwegend manlik. Die teikengroep wat die felste getref word deur MIV/Vigs word dus nie binne die wit kerk verteenwoordig nie. Voortslepende kerklike segregasie en demografiese marginalisasie verdof hierdie gemeenskap se roepstem vir die wit kerke in Suid-Afrika.

\section{INHIBERENDE FAKTORE IN DIE WIT KERK SE BETROKKENHEID BY DIE NOOD IN DIE SWART GEMEENSKAP}

Enkele faktore wat tradisioneel bygedra het en nog bydra tot negatiewe persepsies by die kerk onder die wit gemeenskap teenoor kerke onder die swart gemeenskap kan aangestip word:

\subsection{Die volkskerk ideologie}

Jonker (1998:3) toon aan dat die NG Kerk hom dikwels baie nou vereenselwig het met die Afrikaner se lotgevalle. Die teologiesanalogiese vereenselwiging van sommiges van die Afrikanervolk met die volk van Israel het "Bybelse" sanksionering gebied vir die kanonisering van die apartheidsideologie. Die NG Kerk praat soms nog in terme van "ons" en "hulle". As "hulle" dan gestraf word deur God oor "hulle" permissiewe leefstyl, dan raak dit "ons” nie so direk nie.

\subsection{Konsentriese sirkels vir diakonale werk}

Rossouw (1991:35) identifiseer in die kerk onder die wit gemeenskap konsentriese sirkels vir diakonale werk. Dit beteken dat eers hulp aan die "huisgenote" van eie kerk, taal en volk betoon word voordat na die "ander" uitgereik word. Hierdie konsentriese benadering bring vir die wit kerk te midde van 'n see van swart nood "bevryding”' van 'n groot gewetenslas.

\subsection{Wit kerklike diakonaat is in die verlede vereng tot duur institusionele hantering van nood}

Lombard en du Preez (1997:164) som die Suid-Afrikaanse welsynsdienste tot onlangs toe op as die reaktiewe kuratiewe hantering van probleme, waar min aandag gegee word aan die proaktiewe uitbou van menswaardigheid en menslike kapasiteit. Waar die kerk ook by hierdie kuratiewe welsynsdienste betrokke was, was dit onderneem deur voltyds betaalde, sinodaal beheerde amptenare. Hierdeur is die diakonaat vervreem van die plaaslike gemeente en die gewone lidmaat (Oosthuizen en Strauss 1995:50). Namate hierdie duur diakonaat al hoe minder haalbaar raak as gevolg van verminderde kapitaal in die blanke 
gemeenskap, word die wit kerk al hoe meer magteloos in die aangesig van swart nood.

Die plaaslike amp van diaken is, ten spyte van die dienskarakter wat die bevestigingsformulier uiteensit, dikwels vereng tot die van kollektant en het min te doen gehad met barmharigheidsdiens.

\subsection{Wit meerderwaardigheid}

Ridley (1975:271) beskou meerderwaardigheid jeens ander rassegroepe as 'n universele blanke karaktertrek. Hierin is die wit kerke in SuidAfrika ook geen uitsondering nie. Afrika se eie goed is deur die koloniale missionêre ekspansionisme met minagting hanteer (Kritzinger 1988:107) en veroordeel. Dandala (SABC nuus 31/10/2000) bevestig die swart ervaring van wit meerderwaardigheid op ' $\mathrm{n}$ nuusonderhoud tydens die onlangse konferensie oor rassisme. Hierdie meerderwaardigheid slaan deur in ' $n$ veroordelende houding jeens die swart jeug en MIV/Vigs slagoffers.

\subsection{Onvergenoegdheid met die huidige situasie van "aanvalle teen blankes"}

Die wit kerk beleef die toename in plaasaanvalle as 'n direkte aanval op blankes. Dikwels sien hulle nie dit is deel van die toenemende geweld wat die hele gemeenskap teister nie. Hierdie uitkyk op plaasaanvalle politiseer die saak en verloor uit die oog dat die swart gemeenskap baie erger ly onder die toenemende kriminaliteit in die land.

\section{KERKLIKE OMGEE-BETROKKENHEID BY DIE MIV/ VIGS SLAGOFFER IS DIE “SHIBOLET" VIR GETROUE KERKWEES IN DIE NUWE MILLENNIUM IN DIE NUWE SUID- AFRIKA}

Met die bogemelde aspekte in ag genome, bly dit steeds 'n basiese Christelike opdrag om nie blind te wees vir die nood van ' $\mathrm{n}$ medemens nie. Dit sal nie nodig wees om hiervoor breedvoerige bewyse aan te voer nie! Dit is genoeg om te bevestig dat onbetrokkenheid by die nood van ' $n$ medemens, die geringstes onder hulle, die kerk se geloof "dood" verklaar (Jak 2:14-17); die kerk as geloofsgemeenskap veroordeel (Matt 25:3540); en die kerk se gehoorsaamheid aan die liefdesgebod bevraagteken (Luk 10:25-37). Betrokkenheid wat vereis word is ook nie net ' $\mathrm{n}$ teoretiese jammerhartigheid nie (1 Joh 3:18); ook nie net gerig op die verlossing van die medemens se siel nie (Jak 2:14-17); ook nie net beperk tot ' $n$ paar betaalde amptenare nie; ook nie beperk tot 'n kommissie nie. Dit is die hele kerk se werk. Dit is so deel van die wesenstaak van die kerk soos die Missionêre roeping. Die hele kerk moet in sy gerigtheid en 
intensie bewustelik en prakties betrokke wees by die nood van die MIV/Vigs slagoffer.

\section{HOE KAN DIE KERK BY MIV/VIGS BETROKKE RAAK?}

Hierdie is hopelik een van die brandende vrae wat vandag in die kerklike geledere debatteer word. Die antwoord lê egter nie in 'n kitsprogram nie, maar eerder in ' $\mathrm{n}$ proses, ' $\mathrm{n}$ roete of ' $\mathrm{n}$ koers wat aangedui moet word. Mens sou hierdie 'n nuwe koers kon noem, 'n nuwe manier van dink. Du Toit (1991:229) bepleit 'n nuwe oriëntasiepunt vir die NG Kerk, ná apartheid. Die wit kerk in Afrika sal radikaal (wortels-toe) nuut moet dink oor hulle selfdefiniëring, bestemming en roeping. Die term "paradigmaskuif" word verkies. Hiermee word aangedui dat die onbetrokke kerke bevry moet word uit die ou paradigma van modernisme en blanke Europese meerderwaardigheid. Die meer post-modernistiese benadering sou miskien die kerk ' $\mathrm{n}$ hupstoot in hierdie skuifproses kon gee. Du Toit (1991:229) soek egter meer hierin as net ' $n$ sekulêre paradigmaskuif, in lyn met die veranderings in die denkraam van die gemeenskap. Hy soek dit in 'n radikale herontdekking, op grond van die evangelie as die finale oriëntasiepunt van ons denke, ' $n$ poging om allereers die Koninkryk van God te soek.

\section{HOE SOU SO 'N PARADIGMASKUIF IN BLANKE KERKLIKE DENKE KON REALISEER?}

'n Drieledige luisterproses moet binne die wit kerk plaasvind: ' $n$ luister na binne, ' $n$ luister na Bo, en ' $n$ luister na weerskante. Al luisterend sal die wit kerk se oriëntasie tot swart nood kan verander.

\subsection{Luister na binne}

Met luister na binne word bedoel dat die wit kerk eerlik moet wees oor sy eie doofheid vir die stem van swart gemeenskapsnood en dat die kerk eerlik self sy ernstige tekortkominge in die hantering van die nood sal erken.

Andersyds moet wit kerke saam met swart familiekerke gaan luister na hulle swart broers en susters se formulering van hulle eie nood. Verklarings soos Kerk en Samelewing en projekte soos die VAM (NG Kerk se Algemene Sinodale Kommissie vir Versoening, Armoede en Morele herstel) sal meer geloofwaardig wees as dit geformuleer word nadat sodanige luisterprosesse deurloop is. Hierdie luisterprosesse impliseer interrassige koinonia, luistergeleenthede en besoeke. Hierdie broederlike interaksie gaan strukturele eenheid vooraf en moet dit onderlê. Strukturele kerkeenheid hiersonder is sinloos en leeg.

Luister na binne vra ook dat die wit kerk hulle eie potensiaal sal waardeer en hulleself sal sien as rolspelers in die koms van die Koninkryk 
van die Lig. Hulle eie hantering van wit armoede in die verlede kan bes moontlik goeie stimulasie bied in die nuwe stryd teen swart armoede.

\subsection{Luister na Bo}

Met luister na Bo (die openbaring van God omtrent die kerk se wesensaard, soos opgeteken in die Bybel) word bedoel ' $n$ nuut luister en ' $n$ herlees van die Bybel. As die bril van blanke modernisme afgehaal is, sal ook die Bybel vir die wit Christen in Afrika verrassend anders klink.

In hierdie luisterproses behoort die wit Christen in Afrika te herontdek dat God vanuit sy wese ' $n$ omgee-God is. Hierdie demoderniserende lees van die Bybel sal die stof van die volgende beginsels afblaas:

- Die modernisme was opgewonde oor menslike potensiaal. ' $n$ Herlees van die Bybel sal die menslike potensiaal teologies herdefinieer met ' $n$ groter openheid vir die mens se feilbaarheid en selfsug. Laasgenoemde vernietig alle gesonde verhoudinge wat ' $n$ heel menswees waarborg.

- As God met die stukkende mens besig raak, is sy agenda holisties, met ' $n$ alles inklusiewe shalom (vrede) as die eindresultaat. Verlossing sluit ook verhoudinge tot die self, die naaste, die natuur en God self in.

- Die kerk kan selfs sonder al die organisatoriese strukture steeds prakties wees wat hulle veronderstel is om te wees: ambassadeurs van ' $n$ liefdesryk met hemelse oorsprong en bestemming. Daar lê groot potensiaal opgesluit in die plaaslike gemeente en die gewone gelowiges wat soos sout oral in die gemeenskap ingesprinkel is. Kerkleierskap moet meer bemagtigend (toerustend) betrokke wees in die plaaslike gemeente (Ef 4:11).

- Die plaaslike gemeente behoort ' $n$ "healing community" te wees, ' $n$ verwysingspunt. Die liturgie van die plaaslike gemeente kan met hoop-metafore en hoop-verhale die gemeenskap se kop in 'n tyd van moedeloosheid weer oplig om die koperslang in die woestyn raak te sien.

- Die Nuwe Testamentiese identiteit van die kerk is triomferend, maar lydend; oorwinnend, maar strydend; pelgrims, maar met vaste koers; draers van hoop, te midde van hopeloosheid. Dit moet die moderne kerk uit die dieptes van moedeloosheid trek om weer met hoop antwoorde te formuleer vir ' $\mathrm{n}$ wêreld wat moedeloos geword het. Dit sou sekerlik insluit dat die kerk weer die moed sal hê om bekering en wedergeboorte te preek aan 'n koerslose wêreld. Veral die gemarginaliseerde, vuisvoos, gekritiseerde wit kerk in die Afrika konteks moet weer ' $n$ Bybelse identiteit ontdek. Hy moet herontdek: 
ek is deel van God se raadsplan om hierdie stukkende wêreld weer nuut en mooi te maak. My identiteit lê in my roeping en diensbare gehoorsaamheid aan die opdrag om sout en lig te wees.

- Kerklike betrokkenheid lê op 'n praktiese konkrete vlak en is alles behalwe teorie en mooi woorde.

\subsection{Luister na weerskante}

So moet die kerk ook leer dat hy twee ore en een mond gegee is, met die doel om meer te luister as te praat. As die kerk nie in dialoog met die noodgeteisterdes, die sterwendes, die eensames, die moedeloses, die klein mensies in die gemeenskap kan gaan sit nie, het die kerk, met die suiwerste dogmaties geformuleerde geloofsuitinge, niks vir die wêreld te vertel nie!

' $\mathrm{n}$ Luisterende kerk is ' $\mathrm{n}$ nederige kerk; dit is ' $\mathrm{n}$ op-pad-kerk; dit is ' $n$ kerk wat saam koers en rigting vind en in verwondering kan uitroep: ons het die ster gesien! 'n Luisterende kerk vra nie "wat kan ons vir julle doen?" nie, maar vra: "Kan ons saam met julle loop?" "Kan ons saam met julle soek na die ster?”

\section{TRANSFORMERENDE KRAG VAN 'N NUWE PARA- DIGMA}

Waar hierdie drie luister-aksies plaasvind, sal die kerk (veral die wit kerk in Afrika) transformeer. Die luisterproses sal tot ' $n$ paradigma van omgee lei. Hierdie omgee sal deur die luister-aksies bepaal en gevorm word. Die omgee paradigma wat uit hierdie luister proses voortspruit, kan kortliks beskryf word as ' $\mathrm{n}$ praktiese, nederige, onselfsugtige diensbaarheid, wat gemeente-gebaseer is, en deur lidmate beoefen word.

\section{PRAKTIESE REALISERING VAN HIERDIE NUWE PARADIGMA BINNE DIE KERK}

Hierdie artikel beoog verder om behulpsaam te wees in die ontdekking van ' $n$ praktiese wyse vir kerkwees te midde van die sosiale pandemie van MIV/Vigs. Wat kan die plaaslike kerk prakties doen?

\subsection{Die ecclesia localis binne die geteisterde gemeenskap (arm, swart, jeug, vroulik) as sleutel in die hantering van die MIV/Vigs pandemie}

Greenway (1991:106) sien die plaaslike kerk as “...in the business of developing new people in Christ, people who possess a radically changed worldview, ideas, values, and attitudes... become(ing) partners in and motivators of change in the community..."

Hierdie stelling beteken nie dat die wit kerk uitgefaseer is in die stryd teen MIV/Vigs nie, maar dat die wit kerk sy plek en rol in hierdie 
stryd sal verstaan as ' $\mathrm{n}$ vennoot. Die wit kerk moet dus alles in sy vermoë doen om die swart, arm kerk, waar die vroue en die jeug versamel is, waar die slagoffers van MIV/Vigs, hulle familie en hulle bure, vriende en mede-inwoners versamel is, om daardie kerk met alle moontlike ondersteuning te bedien. Die wit kerk moet kan sê: Ons is beskikbaar, alles wat ons het, is tot julle beskikking om hierdie pandemie te beveg.

So ' $\mathrm{n}$ benadering is lynreg in teenstelling met die tradisionele (dikwels karige) salaris subsidie waartoe die steun van die wit kerk aan die swart kerk in die verlede beperk was. Dit gaan hier om gedeelde visie en missie; dit gaan om 'n gesamentlike roeping en fokus. Instede van ' $n$ paternalistiese verhouding, praat ons eerder van vennootskappe tussen twee gelykes. Die een met die geld sal nie meer die toon aangee nie, maar die een met die nood. En hierdie nood is veel wyer as net 'n selfgerigte oorlewingsnood, en 'n onvolwasse afhanklikheid. Dit gaan om mense wat gered en gehelp moet word, veral buite die kerk. Die vennote staan dan op gelyke voet langs die slagoffers van MIV/Vigs en soek saam na oplossings.

\subsection{Wyses van betrokkenheid}

Scott (1980:252) onderskei die kerk se diakonale werk op drie terreine. Vir die doel van hierdie artikel wil ek dit oorneem:

- "Relief” (hulpverlening) geskied in kort-termyn hulp, diakonaat en pastoraat.

- "Development" (ontwikkeling) sluit in bemagtiging en potensiaal ontsluiting deur opvoeding, selfontdekking en rigtingaanwysing.

- "Liberation" (bevryding met die klem op geregtigheid) geskied waar die kerk nie net mense leer visvang nie, maar die visvang lisensies vir hengel herverdeel. Dit gaan hier om profetiese optrede wat oorsakende onreg in die sisteem aanspreek en transformeer. Die kerk kan nie maar net pleisters plak as die kanker tot diep in die been ingevreet het nie. Die behandeling moet dan ook radikaal (wortels-toe) wees.

\subsubsection{Hulpverlening}

\section{- Bestaansmiddele}

In die plaaslike gemeenskappe ontdek ons menigmaal vigslyers sonder warm klere, sonder warm beddegoed, sonder daaglikse voedsame kos, verwerp deur hulle families. Hulle nood is eenvoudig: 'n warm kombers, of baadjie, ' $n$ pot voedsame sop en miskien iets om wonde mee te ontsmet. Hierdie basiese dinge is meestal in enige gegoede huishouding beskikbaar. Dit kan eenvoudig bymekaar gemaak word en deur die diakens in die swart gemeenskap by geïdentifiseerde mense afgegee word. Daar moet natuurlik daarteen gewaak word dat hierdie kort-termyn 
hulp nie afhanklikheid skep nie, maar hierdie hulp kan baie effektief in samewerking met die VGKSA (of NGKA) diakonieë aangebied word. Gesinne, wyke, kleingroepe of blokke van 'n gemeente kan byvoorbeeld ' $n$ gesin in nood aanneem en van bestaansmiddele voorsien.

\section{- Maatskaplike dienste}

Op die langtermyn moet die MIV/Vigs slagoffer gehelp word om toegang te kry tot die nodige staatstoelaes. Kennis oor wat, waar, hoe en watter dokumentasie benodig word, moet oorgedra word. Die kerk, met goeie grondvlak verteenwoordiging met lidmate in arm swart gemeenskappe, kan vir die staat 'n nodige hand verleen in die konkrete dienslewering aan die armste gemeenskappe. Voortydig moet reëlings getref word vir pleegsorg van minderjarige kinders. Hier is die hulp van die NG Kerk se bestaande maatskaplike strukture van onskatbare waarde.

\section{- Wesies}

Net in KwaZulu Natal projekteer die Departement Welsyn teen die jaar 2005 'n halfmiljoen wesies. Dit lyk of grootskaalse institusionele hulp weens ekonomiese redes nie haalbaar is nie. Die kerk se rol lê eerder op die vlak van die versterking van die veiligheidsnet van die uitgebreide gesinne binne elke gemeenskap. Hulle moet gehelp word om toegang te kry tot toelaes. Voorskoolse kinders moet gehelp word om by sorg sentra (créches) uit te kom, waar hulle as mense gevorm kan word en skoolgereed gemaak kan word. Terselfdertyd bied dit verligting vir die uitgebreide gesin, en gee dit vir die kind wyer blootstelling. Die plaaslike créches kan ook baat by hulp van die kerk se kant.

\section{- Pastoraat}

Waar MIV/Vigs in arm swart gemeenskappe verwoesting saai bestaan daar veral 'n nood aan die opleiding van "gewone" lidmate binne hierdie gemeenskappe in die basiese vaardighede van pastorale berading. Die hantering van vrees vir die dood, skuld, kommer oor kinders, en die hantering van verwerping is maar ' $n$ paar van die sake wat op die grondvlak binne die modder- of die plakkershut aandag vra. Die MIV/Vigs slagoffer se gesin, kinders, en seksmaats het ook ' $n$ dringende nood aan pastoraat. Groot groepe jongmense sit met die vrees: is my seksmaat(s) positief? Is ek positief? Ook hulle het pastoraat nodig. Onderwysers het ook pastorale vaardighede nodig. Ouers van kinders wat positief getoets is, het nie alleen pastoraat nodig nie, maar uiteindelik ook die vaardighede om hulle eie kinders beter te hanteer.

In die Afrika kerk-kultuur word siekes suksesvol deur vroue groepe besoek. Daar word gebid en baie gesing. Hierdie groepsgerigte ondersteuning is in die Afrika kultuur ingebed en is baie nodig. Dit kan 
nie vervang word nie, maar moet deel uitmaak van die aanvullende opleiding wat voorgestel word. Daar bly egter 'n behoefte aan meer persoonlike berading wat universele menslike vrees en behoeftes moet aanspreek. Die staat se Vigs-beraders is ingestel op organiese of biologiese voorligting, en persoonlike menseregte. Die holistiese aanspreek van ook die dieperliggende geestelike behoeftes vra die kerk se unieke aandag.

Hierdie opleiding sal deeglik die Afrika denkstrukture, die armoede kultuur en die Evangeliese hoop moet verreken. Eenvoudige laag geletterde mense moet toegerus word as "bedienaars van die versoening" en "draers van hoop"

\section{- Diakonaat}

Sentraal in die diakonaat aan die MIV/Vigs slagoffers staan die opleiding van tuisversorgers (Home Based Care). Hierdie vrywilligers besoek gesinne van mense wat MIV positief getoets is en help hulle voorberei om hulle gesinslede te versorg. Dit is verstommend om die openheid in die gemeenskap te sien om vrywilligers vir hierdie diens te kry. Vooroordele en primêre gesondheidsvoorligting kry voorkeur in hierdie opleiding. Kursusse word wel deur die Departement Gesondheid voorsien, maar die opleiding kan deur die kerk gefasiliteer word $^{3}$. Aanvullend tot die departementele kursusse vir vrywilligers kan die kerk ook opleiding aanbied in berading, evangelisasie en ander voorligtingsmateriaal.

$2 \quad$ Hierdie lyk na ' $n$ enorme uitdaging aan elke teologiese fakulteit se departement Diakonologie (Praktiese Teologie). Hiermee word nie bedoel dat ' $n$ akademikus agter sy/haar lessenaar moet inskuif en 'n kompilasie van ' $n$ paar vakwetenskaplike boeke oor leke-pastoraat moet saamstel nie. Daar moet eerder met die akademiese arsenaal in die agterkop werkswinkels met leraars en geestelike leiers uit hierdie gemeenskappe gehou word, waar saam iets unieks, prakties, eenvoudig en evangelies saamgesmelt word. Dan sal die mooi Gereformeerde teologie se wiele grond raak en hoop geskep word vir MIV/Vigs lyers. Die opleiding moet ook net nie inval in die nuwe "workshop"-kultuur van ons tyd nie. Dit moet deel wees van 'n proses waar geleer word, saamgestel word, implementeer word, evalueer word, aangepas word, weer toegepas word, weer evalueer word en weer aanpassings gemaak word. So word die MIV/Vigs slagoffer deel van die proses waar die kerk toegerus word om in die toekoms ook weer meer effektief kerk te kan wees. Praat en luister lyk na die hoekstene van hierdie proses.

3 Die kerk kan baie help deur bv. 'n opgedateerde lys van alle vrywilligers aan te hou sodat hulle presies weet wie is waar beskikbaar om slagoffers behulpsaam te wees. Die lys kan telefoon nommers, kontak adresse en straat adresse insluit vir maklike gebruik. 


\section{- Die erediens as plek wat hoop genereer}

Kerke wat ontstaan het uit die Westerse kerke se sendingwerk worstel dikwels nog om die liturgie in eie idioom uit te druk. Die liturgie binne die MIV/Vigs geteisterde gemeenskap het - so het die Afrika Onafhanklike Kerke gewys - ruimte nodig vir openbare voorbidding, as hoopgewende diens. Gesprek rondom die liturgie en die relasie nood/liturgie sou sekerlik kreatiewe gevolge kon hê.

Naas voorbidding bestaan daar ook ' $n$ behoefte aan in die erediens vir mense om hul lot te bekla (weeklag?) en om hulle stories te vertel. Dit kan 'n kosbare element van 'n dialogiese liturgie vorm.

\section{- Koinonia}

Kritzinger (1988:36) vergelyk koinonia met die pen wat die twee lemme van 'n skêr saambind, te wete diakonia en kerugma. Die koinonia in die plaaslike gemeente, onderlinge liefde, word sigbaar in diensbaarheid en het altyd 'n getuienis karakter.

\section{- Woordbediening}

Louw (1988:227) sien MIV/Vigs as geleentheid om die “... onvoorwaardelike karakter van die genade-alleen-boodskap te verkondig en die deernis van die Christelike liefde te demonstreer...", en nie as 'n geleentheid vir eensydige oordeelsprediking nie. Die nood rondom MIV/Vigs vra om Christelike genade en liefde.

\section{- Lewenskwaliteit van die MIV positiewe persoon}

Alhoewel die MIV positiewe persoon nog so lank as tien jaar kan leef, beleef hy/sy ' $n$ verlies aan hoop, menswaardigheid en lewensin. Die kerk kan ' $n$ platform bied aan hierdie mens om steeds diensbaar, voorligtend en van waarde te wees. Juis hierdie benadering vra dat die kerk die dikwels latente veroordelende houding jeens hierdie mense moet afskud.

\subsubsection{Ontwikkeling (bemagtiging)}

\section{- Leierskapsopleiding}

Ten einde hierdie hulpverlening te laat realiseer, sal effektiewe leierskapskoling en -sensitisering moet plaasvind. Voortgesette opleiding vir leraars, en korter spesialis kursusse vir gemeenteleiers vra die aandag van die teologiese fakulteite. Uit die aard van die saak moet die kursusse gemeente gebaseerd wees, ekonomies haalbaar en prakties toepasbaar. Die siening van die bediening moet verskuif van 'n eenman-vertoning deur betaalde amptenare na die bemagtiging van die hele kerk om op grondvlak holisties kerk te wees. Hierdie opleiding sal meer multiprofessioneel aangebied moet word. 
Smit (1995:23) praat in hierdie verband van "proses leierskap”. Dit is ' $n$ leierskap wat vrae vra; doelwitte help formuleer; mense van ' $n$ visie voorsien; help om kultureel ingebed te raak. Hierdie opleiding is gerig op die kerk as ' $n$ lewende organiese sisteem.

\section{- Voorligting en opleiding van die gemeenskap in gesonde lewensvaardighede}

As die kerk ' $n$ unieke, Christelike rol wil speel in die voorligtingswerk om MIV/Vigs te bekamp, kan die kerk weer die basiese gesonde gesinslewe en kuisheid voor die huwelik bevorder.

Die effektiefste manier om dit te doen is seker om as rolmodel in die gemeenskap uit te staan. Hiervoor moet die kerk meer aandag gee aan huweliksverryking, gesinsverryking en ouerverryking. Bestaande goeie kursusse moet saam met die swart kerkleiers toeganklik gemaak word vir ' $n$ Afrika konteks. Die huwelik moet 'n geloofwaardige alternatief wees in 'n post-gesinslewe gemeenskap.

Jongmense het ' $n$ behoefte om ingelig te word aangaande gesonde seksualiteit en verantwoordelike hofmakery. In die Msinga gebied het die plaaslike hospitaal navorsing gedoen oor skoliere se seksuele gedrag (Msinga district health problem solving team 1996). Hulle het bevind dat $65 \%$ van die sekondêre skole se skoliere seksueel aktief is, terwyl byna niemand "veilige seks" beoefen het nie. Deur die KAP (knowledge, attitude, practice) toets het hulle bepaal dat die skoliere almal deeglik voorgelig is (knowledge). Hulle wou ook graag almal kuis leef, met maagde trou en moreel reg optree (attittude), maar hulle praktyk (practice) het die teenoorgestelde getoon. Kennis op sigself werk dus nie altyd voorkomend nie. So ook nie morele opvoeding oor wat reg en verkeerd is nie. Hulle navorsing toon dat gedrag verander waar gesonde rolmodelle sigbaar teenwoordig is, en waar streng konsekwente dissipline tuis van jongs af neergelê, toegepas en gemodelleer word. Daar is geen plaasvervanger vir ' $n$ gesonde gesinslewe nie.

MIV/Vigs is maar net een simptoom van 'n gemeenskap wat vervreemd geraak het van gesonde gesinstrukture. Voorligting aan die jeug sal dus aandag moet gee aan die aanwakker van nuwe drome onder die jeug, drome van gesonde stabiele gesinstrukture. Sonder gesonde rolmodelle binne die kerk binne daardie gemeenskappe self is hierdie poging egter futiel.

In die voorligting aan die jeug blyk die beginsel suksesvol te wees dat jongmense die beste deur jongmense voorgelig word. Hiervoor moet Christen jeugleiers opgelei en toegerus word. 


\subsubsection{Bevryding/Geregtigheid}

Die MIV/Vigs pandemie is meer as ' $n$ virus wat deur liggaamsvloeistowwe oorgedra word. Dit is simptoom van ' $n$ gemeenskap wat moreel bankrot verklaar kan word. Die immoraliteit van die nuwe Suid-Afrikaanse gemeenskap sal in die teiken van die kerk se profetiese verkondiging moet inbeweeg.

Immoraliteit is meer kompleks as net seksuele onkuisheid. Dit raak ook die regte en respek vir die vroulike liggaam, wat veral deur die media verontagsaam word. Dit raak werksure wat nie ruimte laat vir gesinstyd en ouer verantwoordelikhede nie. Dit raak onderbetaling van werknemers.

Die voetsoolvlak kerk binne die armer gemeenskappe word geleentheid tot inspraak gegee in regeringsbeleid, maar moet hiervoor opgelei en motiveer word. In hierdie proses van "advocacy" kan kerkleiding 'n prominente rol speel. Verby is die dae dat die kerk se stem verteenwoordig sal word deur minderhede. Die kerk sal moet leer om gemeenskappe op te lei in die uitdruk van hulle Christelike waardes in versoekskrifte en memorandums. Die kerk sal die massas moet profeties aktief kry, aangesien hulle stem die enigste hoorbare stem in 'n sekulere, demokratiese bedeling is.

\section{SOUT VAN DIE AARDE}

Die kerk is in die nuwe Suid-Afrika geroep om sout te wees. Die wit kerk is nie hierby uitgesluit nie. Die wit kerk sal egter alleen suksesvol wees as hy luister en luisterend dienaar word met 'n nuwe identiteit in Christus.

\section{Literatuurverwysings}

Dandala, M SABC-Nuusonderhoud 31/10/2000.

Du Toit, D A 1991. Die NG Kerk en kerkeenheid. NGTT 32(2):223-231.

Greenway, R S 1991. Mission now this generation. GR/Michigan: Baker Book House.

Jonker, W D 1998. Selfs die kerk kan verander. Kaapstad:Tafelberg.

Kritzinger, J J 1988. The SA context of Mission. Kaapstad: Lux Verbi.

Lombard A \& Du Preez, J 1997. Social welfare: Shifting from a curative to a developmental paradigm. In: W Vosloo (red), 164-179.

Louw, D J1988. Vigshisterie of pastorale strategië vd bediening. Tydskrif vir geesteswetenskappe 28(3):225-253 
Msinga District health problem solving team. Maart 1996. Focus problem: STD in High Schools. Ongepubliseerde navorsing onder supervisie van die Universiteit van Natal se sentrum vir gesondheid en sosiale studies (CHESS).

Oosthuizen, A \& Strauss, P 1995. Gemeentediakonaat as plaasvervanger vir staatsondersteunde sinodale barmhartigheidsdiens in die NG Kerk. Acta Theologica 1995(2):50-65.

Ridley, E J 1975.Pastoral care and the black community. Journal of Pastoral Care 29(1):271-276.

Rossouw, P J 1991. Die tuiskoms van die Ned. Geref. Kerk? 'n Visie op gemeentewees in Suid-Afrika in die jare 90. UV Teologiese studies no.5:33-47.

Scott, W 1980. Bring forth justice. GR/Michigan:Eerdmans.

Smit, A (red) 1995. Nuutgedink oor leierskap in gemeentes. Die begeleiding van Christelike geloofsgemeenskappe. Kaapstad: Lux Verbi.

Vosloo, W (red) 1997. Perspektiewe op ' $n$ veranderende en verarmende gemeenskap. Pretoria:SEVTO. 